 \\ UF $\mid$ FLORIDA

\author{
Hrimsamen
}

\section{Black soldier fly Hermetia illucens Linnaeus (Insecta: Diptera: Stratiomyidae) ${ }^{1}$}

Joseph W. Diclaro II and Phillip E. Kaufman²

\section{Introduction}

The black soldier fly, Hermetia illucens (Linnaeus), is a sleek looking fly that many confuse with a wasp. However, like most flies, the black soldier flies only have two wings (wasps have four) and does not possess a stinger. Although the loud buzzing they create when flying is enough to concern many people, adult soldier flies pose no danger.

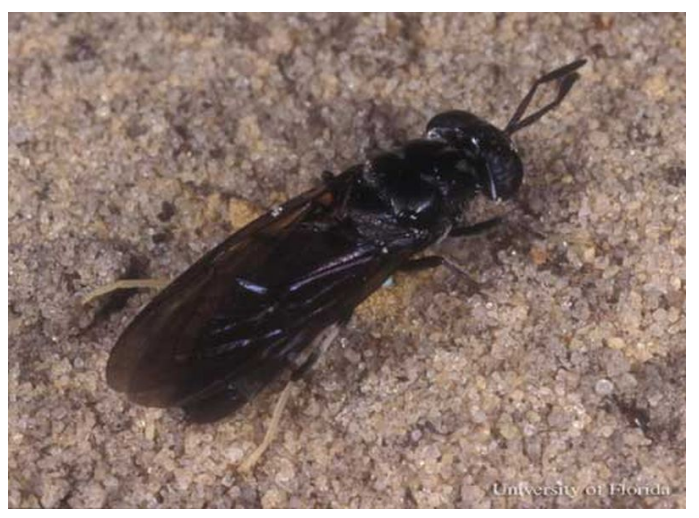

Figure 1. Adult black soldier fly, Hermetia illucens (Linnaeus). Credits: Lyle J. Buss, University of Florida

The black soldier fly is often associated with the outdoors and livestock, usually around decaying organic matter such as animal waste or plant material. Since the black soldier fly larvae consumes decaying matter, they have been used to reduce animal manure in commercial swine and poultry facilities (Newton 2005). Although they are not known as a disease vector, adult soldier flies are a potential mechanical vector of various pathogens. A more likely negative interaction would be accidental ingestion of black soldier fly larvae by animals or humans. (Goddard 2003).

\section{Synonymy}

Musca illucens Linnaeus, 1758

Musca leucopa Linnaeus, 1767

Hermetia rufiventris Fabricius, 1805

Hermetia pellucens Macquart, 1834

Hermetia nigrifacies Bigot, 1879

Hermetia mucens Riley \& Howard, 1889

1. This document is EENY-461, one of a series of Featured Creatures from the Entomology and Nematology Department, Florida Cooperative Extension Service, Institute of Food and Agricultural Sciences, University of Florida. Published: June 2009. This document is also available on Featured Creatures Web site at http://creatures.ifas.ufl.edu. Please visit the EDIS Web site at http://edis.ifas.ufl.edu. Additional information on these organisms, including many color photographs, is available at the Entomology and Nematology Department website at http://entnemdept.ifas.ufl.edu/

2. Joseph W. Diclaro II, graduate student in medical entomology; and Phillip E. Kaufman, assistant professor of veterinary entomology, Department of Entomology and Nematology, Institute of Food and Agricultural Sciences, University of Florida, Gainesville, 32611.

The Institute of Food and Agricultural Sciences (IFAS) is an Equal Opportunity Institution authorized to provide research, educational information and other services only to individuals and institutions that function with non-discrimination with respect to race, creed, color, religion, age, disability, sex, sexual orientation, marital status, national origin, political opinions or affiliations. U.S. Department of Agriculture, Cooperative Extension Service, University of Florida, IFAS, Florida A. \& M. University Cooperative Extension Program, and Boards of County Commissioners Cooperating. Millie Ferrer, Interim Dean 


\section{Hermetia illucens var. nigritibia Enderlein, 1914}

Hermetia illucens Copello, 1926

List generated from (ITIS 2009)

\section{Distribution}

The family Stratiomyidae comprises 260 known species in North America (Triplehorn 2005). In the southeastern United States, the black soldier fly is abundant during late spring and early fall, and has three generations per year in Georgia (Tomberlin et al. 2002). While common in the continental United States, this fly is found throughout the Western Hemisphere.

In natural breeding sites (i.e. carrion) black soldier flies lay their eggs in moist organic material. Black soldier flies frequent agricultural settings because the large amounts of organic waste left by livestock offer abundant sites that meet their reproductive needs. In areas where natural habitats are removed (urbanized areas) the black soldier fly will lay eggs in dumpsters or compost, which provide similar odors and nutritional needs to naturally occurring organic matter. This is especially true for areas with poor sanitation.

\section{Description and Life Cycle}

Adults: Members of the soldier fly family Stratiomyidae can range in color from yellow, green, black or blue, with some having a metallic appearance. Many are mimics of other flying insects, such as bees and wasps. Black soldier fly adults have a wasp-like appearance and are black or blue in color. Soldier flies also have two translucent "windows" located on the first abdominal segment. Adults range from 15 to $20 \mathrm{~mm}$ in length. (Sheppard et al. 2002). The adult's antennae are elongated with three segments, and legs have white coloration near the end of each leg.

Two days after adult emergence from the pupal case, mating can occur. A male black soldier fly intercepts a passing female in mid-air and they descend in copula (Tomberlin and Sheppard 2001). Male soldier flies utilize lekking sites, where they

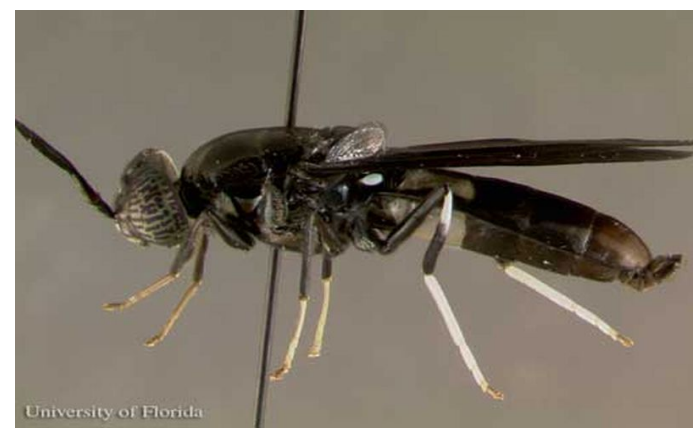

Figure 2. Lateral view of an adult black soldier fly, Hermetia illucens (Linnaeus). Notice the two translucent "windows" located on the first abdominal segment, partially obscured in this image by the rear leg. Credits: Bianca Diclaro, University of Florida

await female soldier flies. These sites are defended against other male soldier flies. When a male intrudes upon the territory of a resting male, the resting male seizes the intruder. After a brief descent, the invading male will retreat.

Eggs: The female black soldier fly deposits a mass of about 500 eggs in cracks and crevices near or in decaying matter such as dung, carrion, garbage, and other organic waste. The eggs hatch into larvae in about four days. Each oval shaped egg is about $1 \mathrm{~mm}$ in length, and pale yellow or creamy white in color (NCIPMI 1998).

Larvae: The larvae can reach $27 \mathrm{~mm}$ in length and $6 \mathrm{~mm}$ in width. They are a dull, whitish color with a small, projecting head containing chewing mouthparts. Larvae pass through six instars and require approximately 14 days to complete development (Hall and Gerhardt 2002). During larval development, black soldier fly larvae are insatiable feeders. As adults they do not need to feed and rely on the fats stored from the larval stage (Newton et al. 2005).

Pupae: Before pupation, the sixth instar larvae disperse from the feeding site to dry sheltered areas, such as ground vegetation, to initiate pupation. The exoskeleton (skin) darkens and a pupa develops within. Pupation requires about two weeks (Hall and Gerhardt 2002). 


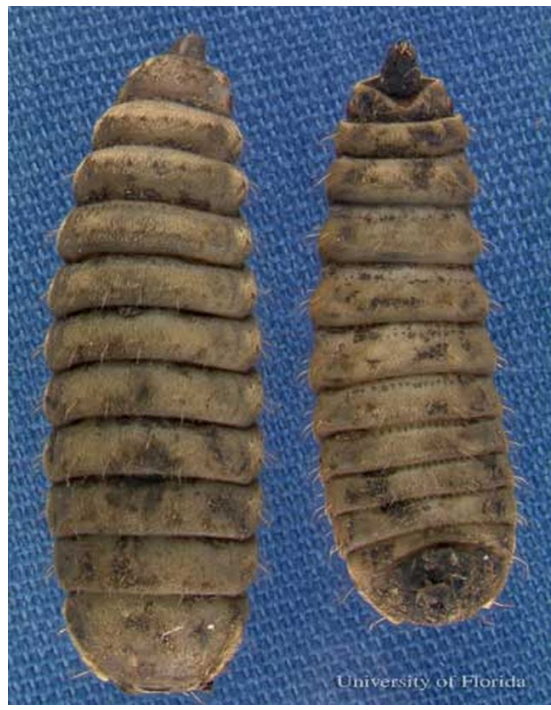

Figure 3. Dorsal (left) and ventral (right) views of sixth instar larvae of the black soldier fly, Hermetia illucens (Linnaeus). Credits: Bianca Diclaro, University of Florida

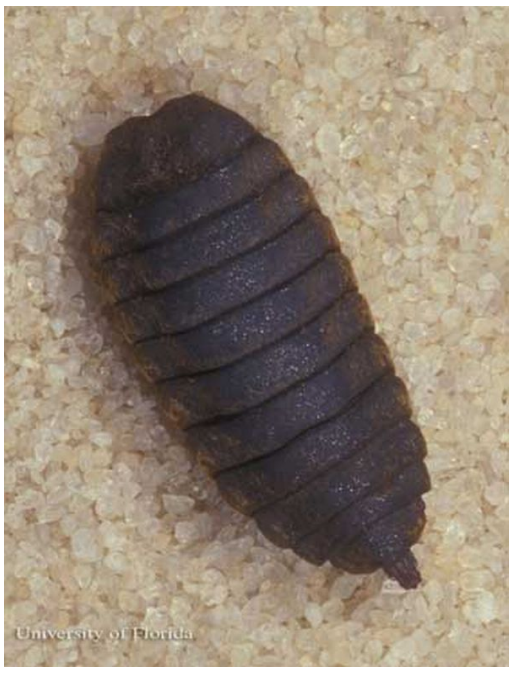

Figure 4. Pupa of the black soldier fly, Hermetia illucens (Linnaeus). Credits: James Castner, University of Florida

\section{Economic Importance}

The adult black soldier fly is not usually considered a pest (Newton et al. 2005). Because the larvae have been shown to be effective manure recyclers, a "Black Soldier Fly Manure Management System" has been proposed to not only reduce livestock waste, but also generate a food source for fish and other animals. In a program outlined in Newton et al. (2005) swine manure was fed to black soldier fly larvae, which greatly reduced the waste material. The manure was transferred into a basin containing black soldier fly larvae. As the larvae developed they reduced the manure by $50 \%$.
Approximately 45,000 larvae will consume $24 \mathrm{~kg}$ of swine manure in 14 days. As the larvae mature they crawl out of the basin, thereby self-harvesting themselves, and are subsequently available as livestock feed. In addition to being a good source of oil and protein for animal feed, black soldier fly larvae have the potential of improving organic waste into a rich fertilizer.

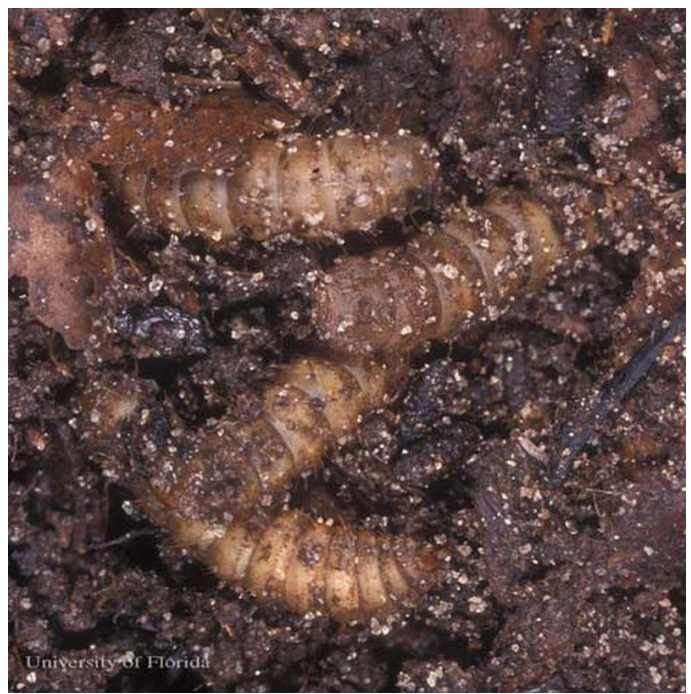

Figure 5. Larvae of the black soldier fly, Hermetia illucens (Linnaeus), in compost. Credits: Lyle J. Buss, University of Florida

\section{Selected References}

- Drees BM, Jackman J. (October 2008). Soldier fly. A Field Guide to Common Texas Insects. http://insects.tamu.edu/fieldguide/cimg226.html (14 July 2009).

- Goddard, J. 2003. Physician's Guide to Arthropods of Medical Importance, 4th Edition. CRC Press LLC. Boca Raton, Florida.

- Hall DC, Gerhardt RR. 2002. Flies (Diptera), pp 127-161. In Mullen G, Durden L. (editors). Medical and Veterinary Entomology. Academic Press. San Diego, California.

- ITIS. (2009). Hermetia illucens Linnaeus. Integrated Taxonomic Information System. http://www.itis.gov/servlet/SingleRpt/ SingleRpt?search_topic $=$ TSN\&search_value $=13$ 0298 (14 July 2009). 
- NCIPMI. (1998). Insect and related pests of man and animals. North Carolina Integrated Pest Management Information. http://ipm.ncsu.edu/AG369/notes/ black_soldier_fly.html (14 July 2009).

- Newton L, Sheppard C, Watson DW, Burtle G, Dove, R. (June 2005). Using the black soldier fly, Hermetia illucens, as a value-added tool for the management of swine manure. Waste Management Programs. North Carolina State University. http://www.cals.ncsu.edu/waste_mgt/ smithfield_projects/phase2report05/cd, web\%20files/A2.pdf (14 July 2009).

- Sheppard DC, Tomberlin JK, Joyce JA, Kiser BC, Sumner SM. 2002. Rearing methods for the black soldier fly (Diptera: Stratiomyidae).

Journal of Medical Entomology 39: 695-698.

- Tomberlin JK, Sheppard DC. 2001. Lekking behavior of the black soldier fly (Diptera: Stratiomyidae). Florida Entomologist 84:

729-730.

- Tomberlin JK, Sheppard DC, Joyce JA. 2002. Selected life history traits of black soldier flies (Diptera: Stratiomyidae) reared on three artificial diets. Annals of the Entomological Society of America 95: 379-386.

- Triplehorn CA, Johnson NF. 2005. Borror and Delong's Introduction to the Study of Insects, 7th Edition. Thomson Brooks/Cole. Belmont, California. 864 pp. 